\title{
STRUCTURAL AND SEMANTIC PECULIARITIES \\ OF THE GERMAN-LANGUAGE TERMINOLOGICAL SYSTEM OF LOGISTICS
}

\section{Tetiana Harmash}

Candidate of Pedagogical Sciences, Assistant Professor,

National Aviation University, Ukraine

e-mail: tetiana.harmash@npp.nau.edu.ua, orcid.org/0000-0001-6691-4815

\author{
Nataliia Khaidari \\ Candidate of Pedagogical Sciences, Senior Lecturer, \\ National Aviation University, Ukraine \\ e-mail: nataliia.khaidari@npp.nau.edu.ua,orcid.org/0000-0001-7283-0159
}

\section{Summary}

The article reveals trends in word formation process that are typical for the modern German language terminological system of logistics, examines composition as a means of nominating the concepts of this terminological system in modern German. The concept of "composite term" from the point of view of logistics is understood as a complex word that nominates a certain concept in the field of logistics and formed by combining two or more independent words, their stems and/or root morphemes is defined. A structural and typological analysis of complex German terms of logistics on the material of complex terms of logistics, selected from the dictionary presented on the professional online resource LOGISTIK-LEXIKON.DE, and found that German language terminological combinations can be divided into two-, threefour-component composites. The most common type of complex logistical composite terms of the German language are two-component terms (73\%); three-component terms are presented in a much smaller number $(26.5 \%)$, the number of four- component complex terms in the analyzed resource made up 4 terminological units $(0.5 \%)$. Morphological analysis of complex terms of German logistics terminology showed that they have different components. It was found that the terminology of logistics industry is substantive one, and the second component is often a noun, and as a determinant are the following parts of speech: noun, adjective, adverb, pronoun and preposition.

Keywords: word formation, terminology, terminological units, logistics, professional communication.

\section{DOI: https://doi.org/10.23856/3803}

\section{Introduction}

In today's globalized world, the exchange of information and related documentation is growing exponentially. An important component of scientific and technological and economic progress is the terminology, which plays a crucial role in professional communication. The development of civilization and the constant growth of information scope is accompanied by the emergence of numerous terms, and professional vocabulary is the vast majority of modern linguistic fund. According to Yu. Dorokhova, the growth of the number of terms of different sciences is ahead of the growth of the number of commonly used words, so now the number of terms of individual sciences exceeds the number of non-special words of the language (Dorokhova, 2007). Terminological vocabulary occupies a prominent place in the vocabulary of any developed literary language. Continuously replenished with new units, it is the part 
of the dictionary, which development is the most intensive. The study of the peculiarities of terms' interpretation is important not only because of the significant prevalence of this phenomenon, but also due to importance of the reality of reflection of actual reality in the translation. In addition, such researches are necessary for development of science and improvement of the process of new terms formation in various fields of science and technology. In this regard, O. Gerd notes: "A term is a unit of any natural or artificial language (usually a word or phrase) that existed before or was specially created and has a special terminological meaning, which is expressed either in verbal form or in that or in another formalized form and quite accurately and completely reflects the basic, essential at the outlined level of development of science, the peculiarities of the existing scientific concept" (Gerd, 1991: 2).

Terms and their combinations, created on the basis of concepts, lexical and semantic relations, as well as at their word-forming and grammatical levels, are an essential part of the general language and are inseparable from it (Gak, 1971: 79). It is the understanding of the inseparable connection between terminology and units of the national language, as well as the identification of the peculiarities of the term as a special type of word that marks the beginning of a new stage in the development of terminology. The issue of terminology of logistics has recently attracted the attention of a number of domestic and foreign specialists in the fields of economic knowledge (Horbenko, 2012; Hryhorak, Kazymyrova, 2011; Ohienko, Dziobko, 2009; Kuptsova, 2007; Reser, Rodnikov, 2007; Smyrchynskyi, 2000; Sergeev, 2008; Sterligov, 2006; Sterligova, 2004). However, very little researches in this area belongs to philologists; mostly these are individual works, in which the issues of standardization and codification of logistics terms are raised (Dorokhova, 2019; Kuptsova, 2007), as well as the principles of compiling a terminological dictionary of this field (Hryhorak, Kazymyrova, 2011). A comprehensive study of the terminology of logistics on the material of the Ukrainian language was carried out in the dissertation research of $\mathrm{H}$. Karpenko (Karpenko, 2018), some aspects of logistics terminology were considered in the research of T. Harmash (Harmash, 2017, 2019).

However, the current state of Ukrainian scientific terminology is characterized by growing interest in international standards and at the same time increasing interest in their own national heritage (Kovtun, 2017: 261), thus it is important to understand the connection between Ukrainian logistics terminological system and proper terminological systems of European advanced countries for successful integration of domestic logistics in the world one. Germany is considered to be one of the leading countries in the application of the latest concepts and technologies of integrated logistics and SCM (Supply Chain Management) (Dorokhova, 2019). The need to analyze the peculiarities of oral and written communication in the Ukrainian and German professional languages of the logistics sphere became the basis for our research. Its main purpose is to identify trends in the process of word formation, which are distinctive ones for terminological system of the modern German language in the field of logistics. The issues of modern word formation of the German language are examined in the works of such German scientists as J. Erben (Erben, 2006), W. Fleischer, I. Bartz (Fleischer, Barz, 2012), W. Motsch (Motsch, 2004), M. Lohde (Lohde, 2006), etc. The substantive word formation of the German language was the object of the study of the Russian scientist V. Vashunin (Vashunin, 1990), the verbal one - N. Smoliar (Smoliar, 2011). V. Karpiuk (Karpiuk, 2010) studied the peculiarities of the typology of word formation in the context of the neology of the modern German language. Modern German word-formation studies are represented by the works of N. Hura (Hura, 2017), A. Statkevych, O. Fenchuk (Statkevych, Fenchuk, 2010), in which the authors investigated the complex terms of the computer industry; in the study of O. Kucherenko (Kucherenko, 2013) the lexical innovations of the Ukrainian and German systems of terms in the field of civil protection 
are examined. However, even the most thorough of these studies have no structural and typological analysis of complex German terms in the logistics field. The urgency of the work is determined by the need to study the processes of formation of composite terms of the logistics sector, as well as the insufficient level of research of composites in German texts of the logistics field and the development of this issue in terms of word-forming peculiarities. The research was performed on the basis of complex terms of logistics, selected from the dictionary presented on the professional online resource LOGISTIK-LEXIKON.DE [www.logistik-lexikon.de] (the sample made up 654 terms).

\section{Definition of the term "composite term"}

In German, the most productive way of word formation is word composition (Kucherenko, 2013). That is why the new German words, including terms, in their vast majority "are created through the formation of composites" (Arkhypova, 2000: 6). In Ukrainian and foreign Germanic philology one can find different interpretations of the concept of lexical composition. M. Lohde interprets German composites as complex words of hierarchical structure, in which each independent component can be subject to the following division (Lohde, 2006: 36). V. Levytskyi understands composition as the creation of words by combining two or more independent components, emphasizing the binary nature of most composites, highlighting two direct components in their structure (Levytskyi, 2014: 194). G. Elsen considers a composite as a combination of at least two root morphemes. At the same time, the scientist refers both basic (root) morphemes and confixes, individual letters and symbols to meaningful creative elements. (Elsen, 2009: 58). The scientist believes that multicomponent complex words are typical for multidisciplinary professional texts, as they are an economical way to convey information and scientific knowledge optimally and accurately.

We, in turn, based on the above mentioned in our study, define a composite term as a complex word that nominates a concept in the field of logistics that is formed by combining two or more independent words, their bases and/or root morphemes.

\section{Classification of composite terms}

We classified the selected composites according to various criteria, namely: a) by the number of forming bases; b) by the type of grammatical and syntactic connections between the components; c) by genetic sources of origin of forming elements.

Depending on the number of individual words or root morphemes that are part of the logistic terms, we divide them into two-component, three-component and multi-component composites.

A great part among the studied lexical units make two-stem compound terms: die Allgefahrendeckung, die Artikelklassifizierung, die Bedarfsermittlung, die Begegnungsverkehr, das Begleitpapier, die Transportversicherung, etc. Nominating the key concepts of the terminological system of logistics, two-component lexical items meet the requirements of accuracy and brevity, which are put forward by many linguists in relation to the term. Three-component composites with different types of grammatical links between their components are also often used, for example: das Ausfuhrbegleitdokument, die Einzelauftragskommissionierung, die Kapitalrückflusszeit, etc. Among the advantages of this method of word formation, scientists note the compactness and economy of the form of terminological nomination, as well as the accuracy of displaying the peculiarities of the term in the appropriate terminological field to denote various 
objects of reality. In addition, complex terms are always shorter than word combinations, and are integral, that is, there is no need for grammatical design of the first component, which plays a particularly important role, especially in writing. The structure of a complex word is always binary and the main word is a formal and informational core of a multicomponent complex word and defines grammatical categories of a complex word, such as gender, number, case, and the determinant clarifies, supplements, expands the information conveyed by the main word. In turn, a determinative can consist of two or more words that are translated as different parts of speech (Erben, 2006).

Thus, depending on the number of components, the German-language terminological combinations of the logistics field that have been analyzed can be divided into two-, three- and four-component ones. The results of the study allowed us to conclude that the most common type of complex logistics composite terms of the German language are two-component terms (73\%): der Absatz + die Logistik = die Absatzlogistik, begleiten + das Papier = das Begleitpapier, die Beschaffung + die Strategie = die Beschaffungsstrategie, die Distribution + die Logistik = die Distributionslogistik, die Einlagerung + der Schein = der Einlagerungsschein, die Karussell + das Regal $=$ das Karussellregal. Three-component terms are presented in a much smaller number (26.5\%). For example: das Einzel + auftragen + die Kommissionierung $=$ die Einzelauftragskommissionierung, frei + der Platz + das System $=$ das Freiplatzsystem, die Güte + der Verkehr + das Zentrum = das Güterverkehrszentrum, kennen + die Zeichnung + der Pflicht $=$ der Kennzeichnungspflicht, die Luft + der Fracht + der Brief $=$ der Luftfrachtbrief. The number of four-component complex terms in the analyzed resource is insignificant, only 4 terminological units $(0.5 \%)$ : der Kapital + rücken + der Fluss + die Zeit = die Kapitalrückflusszei; die Palette + die Fläche + das Regal + der Lager = der Palettenflachregallager; der Fach + der Boden + das Regal + der Lager = der Fachbodenregallager; der Bau + die Kasten + der Stück + die Liste = die Baukastenstückliste. N. Hura explains this by the fact that composites, which are formed from more than three bases, complicate understanding and do not meet the conditions of brevity and clarity, which the term should meet (Hura, 2017).

Morphological analysis of complex terms of German logistics terminology showed that they have different components. Since the terminology of the logistics industry is substantive one, the second component is often a noun, and the first component can be: noun (der Lager + die Logistik = die Lagerlogistik, die Begegnung + der Verkehr $=$ der Begegnungsverkehr $)$, adjective (fest + der Abruf $=$ der Festabruf, langsam + der Dreher = der Langsamdreher, bereit + die Stellung = die Bereitstellung), verb (liefern + die Qualität $=$ die Lieferqualität, entladen + die Stelle = die Entladestelle, ist + bestand $=$ der Istbestand $)$, adverb $($ mehr + der Weg + die Verpackung = die Mehrwegverpackung, nieder + der Flur + der Förderer $=$ der Niederflurförderer), numeral (zwei + die Hand + die Bedienung = das Zweihandbedienung, ein + der Schub + das Regal $=$ das Einschubregal $)$, pronoun $($ all + die Gefahren + die Deckung $=$ die Allgefahrendeckung) and preposition (zwischen + der Lager $=$ der Zwischenlager, nach + die Lieferung = die Nachlieferung).

However, it should be emphasized that productivity of different parts of speech in the process of creation of composite terms is not the same. The most functional ones are noun stems. The most used is the model $\mathrm{S}+\mathrm{S}=\mathrm{S}(71 \%)$ : die Kennzeichnung + die Pflicht $=$ die Kennzeichnungspflicht, die Qualität + die Kontrolle = die Qualitätskontrolle. For complex terms with an adjective as a main component is commonly used the following word-formation model: $\mathrm{S}+\mathrm{Adj}=\mathrm{Adj}$ : die Saison + bedingte $=$ saisonbedingte, der Auftrag + orientiert $=$ auftragsorientierter, der Artikel + orientiert $=$ artikelorientiert, der Prozess + orientiert $=$ prozessorientiert, das Akkreditiv + konform $=$ akkreditivkonform, das Papier + los $=$ papierlos $\mathrm{V}+\mathrm{Adj}=\mathrm{Adj}$ : 
bestellen + fix $=$ bestellfix. The terms of these models indicate the subject-qualitative characteristics of the concept.

Despite the tendency of professional terminology to save language resources, three-component and four-component logistic terms, as already was mentioned, are used much less frequently than two- component ones. Usually they express a kind of a concept, serve to differentiate the meaning of the main word. The most productive are the three-component terms, which are formed according to the model $\mathrm{S}+\mathrm{S}+\mathrm{S}=\mathrm{S}$ : das Kapital + der Rückfluss + die Zeit $=$ die Kapitalrückflusszeit, der Teil + die Verwendung + der Nachweis $=$ der Teilverwendungsnachweis, der Kragarm + das Regal + das Lager = das Kragarmregallager, die Waren + der Verkehr + die Bescheinigung = die Warenverkehrsbescheinigung. The number of terms represented by the model $\mathrm{Adj}+\mathrm{S}+\mathrm{S}=\mathrm{S}$ is insignificant, for example: klein + die Teile + das Lager $=$ das Kleinteilelager.

The total number of four-component logistic terms found in the resource we analyzed is small and is represented by the model $\mathrm{S}+\mathrm{S}+\mathrm{S}+\mathrm{S}=\mathrm{S}$ : die Palette + die Fläche + das Regal + der Lager $=$ der Palettenflachregallager, der Fach + der Boden + das Regal + der Lager $=$ der Fachbodenregallager, der Bau + die Kasten + der Stück + die Liste = die Baukastenstückliste.

German logistics terminology has been formed under the influence of different factors, which led to the heterogeneity of its composition. As a result of etymological analysis of the components of complex terms of the logistics industry, it was found that specific German vocabulary is combined with borrowed one, word formation is represented by lexical units, which are formed by three models: 1) combination of two or more German creative bases (der Buchbestand); 2) combination of several foreign language terminological elements (der Bring-Prinzip); 3) combination of borrowed words and morphemes with autochtonous German stems, resulting in so-called "hybrid composites" (Bondar, 2016). For example, the composite die Blisterverpackung is formed by combining the English word der Blister and the German one - die Verpackung; another complex word is der Containersammeldienst that has three components: the English borrowing der Container, the verb sammeln, and the noun der Dienst.

\section{Conclusions}

The conducted structural and syntactic analysis of the German language composites of the logistics field allowed us to establish a certain specificity of word formation in the analyzed terminological system. Structurally, two-component and three-component composites with a determinative type of connection between the main components predominate. The construction of such multi-component terms makes it possible to carry out multifaceted characteristic of complex logistics concepts. It is established that the productivity of different parts of speech in the creation of composite terms is not the same. The most functional are nouns. There is a tendency to involve English lexical units in the creation of hybrid complex terms of different combinations. The revealed peculiarities of word formation in the German language terminological system of the logistics industry open the prospect of further research of other ways of word-formation nomination of logistics concepts, in particular affixation and abbreviation.

\section{References}

Arhipova I. V. (2000). Nemetskie derevativyi v perevode na russkiy yazyik [Translation of German derivatives into Russian]. Teoriya i praktika germanskih i romanskih yazyikov, 160-163. [in Russian] 
Bondar N. V. (2016). Slovoskladannia yak sposib nominatsii poniat hastroenterolohii v suchasnii nimetskii movi [Word composition as a way of nominating the concepts of gastroenterology in modern German.]. Molodyi vchenyi, 2, 360-363. [in Ukrainian]

Vashunin V. S. (1990). Substantivnyie slozhnyie slova v nemetskom yazyike [Substantive compound words in German]. Moskow: Vyisshaya shkola. [in Russian]

Gak V. G. (1971). Asimmetriya lingvisticheskogo znaka i nekotoryie obschie problemyi terminologii [Asymmetry of the linguistic sign and some general problems of terminology.]. Semioticheskie problemyi yazyikov nauki, terminologii i informatiki, 2, 78-84. [in Russian]

Harmash T. A. (2017). Zelena lohistyka: terminolohichni aspekty [Green logistics: terminological aspects.]. Avia-2017. Retrieved from http://avia.nau.edu.ua/doc/avia-2017/AVIA_2017.pdf [in Ukrainian]

Harmash T. A. (2019). Vidtvorennia nimetskykh lohistychnykh terminiv-kompozytiv u perekladi [Reproduction of German logistic composite terms in translation]. Zakarpatski filolohichni studii: zbirnyk naukovykh prats, 8, 43-49. [in Ukrainian]

Gerd A.S. (1991). Znachenie termina i nauchnoe znanie [The meaning of the term and scientific knowledge.]. Nauchnotehnicheskaya informatsiya. Ser. 2, 10, 1-4. [in Russian]

Dzobko I. P., Ohiienko S. O. (2009). Hlosarii lohistychnykh terminiv [Glossary of logistics terms]. Kharkiv: Vyd. KhNEU. [in Ukrainian]

Hryhorak M., Kazymyrova I. (2011). Prospekt slovnyka "Lohistyka. Slovnyk terminiv" [Prospectus of the dictionary "Logistics. Glossary of terms"]. Leksykohrafichnyi biuleten: zb. nauk. prats, 24-32. [in Ukrainian]

Horbenko O. V. (2012). Terminolohichnyi aparat vitchyznianoi lohistyky [Terminological apparatus of domestic logistics]. Upravlenye proektamy, systemnbii analyz y lohystyka, 10, 420-427. [in Ukrainian]

Hura N. P. (2017). Strukturno-typolohichni osoblyvosti skladnykh nimetskykh kompiuternykh terminiv ta yikh pereklad ukrainskoiu movoiu [Structural and typological peculiarities of complex German computer terms and their translation into Ukrainian.]. Naukovi zapysky Nizhynskoho derzhavnoho universytetu im. Mykoly Hoholia. Filolohichni nauky, 1, 150-154. [in Ukrainian] Dorohova Yu. E. (2008). Nemetskaya i russkaya terminologiya logistiki: ontologii, modelirovanie terminosistemyi i sopostavitelnyiy analiz [German and Russian logistics terminology: ontologies, terminology modeling and comparative analysis.]. Retrieved from http:www.hse.ru/ science/scifund/ind2007-rep [in Russian]

Karpenko H. P. (2018). Lohistychna terminolohiia ukrainskoi movy [Logistic terminology of the Ukrainian language.]. Dysertatsiia na zdobuttia naukovoho stupenia kandydata filolohichnykh nauk (doktora filosofii) zi spetsialnosti 10.02.01 - ukrainska mova. - Natsionalnyi pedahohichnyi universytet im. M. P. Drahomanova, Kyiv. [in Ukrainian]

Karpiuk V. A. (2010). Osoblyvosti typolohii slovoskladannia v konteksti neolohii suchasnoi nimetskoi movy [Peculiarities of typology of word formation in the context of neology of modern German]. Naukovyi visnyk VDU im. Lesi Ukrainky. Filolohichni nauky, 8, 427-431. [in Ukrainian]

Kovtun O. V. (2017). Ukrainska aviatsiina terminolohiia: linhvistychnyi ta leksykohrafichnyi analiz [Ukrainian aviation terminology: linguistic and lexicographic analysis]. Ukrajinistika na sveučilištu u Zagrebu: 20 godina: zb. nauk. prats, 260-271. [in Ukrainian]

Kuptsova A. K. (2007). Problemyi formirovaniya terminologiy novyih nauk (na primere logistiki) [Problems of the formation of terminologies of new sciences (on the example of logistics)]: avtoref. dis. na soiskanie uch. stepeni kand. filol. nauk: spets. 10.02.04-germanskie yazyiki. Moskow. 17 s. [in Ukrainian] 
Kucherenko O. (2013). Terminy-kompozyty v systemi suchasnoi nimetskoi terminolohii tsyvilnoho zakhystu [Composite terms in the system of modern German civil defense terminology]. Visnyk Natsionalnoho universytetu «Lvivska politekhnika». Seriia: Problemy ukrainskoi terminolohii, 765, 51-55. [in Ukrainian]

Levytskyi V. V. (2014). Leksykolohiia nimetskoi movy [Lexicology of the German language]: posibnyk. Vinnytsia: Nova Knyha. [in Ukrainian]

Leontev R. G. (2007). "Kvazilogistika” "psevdologistika” v transportnoy sfere: ot prenebrezheniya $k$ teorii i metodologii ["Quasi-logistics" "pseudologistics" in the transport sector: from neglection to theory and methodology.]. Byulleten transportnoy informatsii. Inf.-prakt. zhurnal, 11 (149), 21-33. [in Russian]

Rezer S. M., Rodnikov A. N., (2007). Logistika. Slovar terminov [Logistics. Glossary of terms]. Moskow: VINITI RAN. [in Russian]

Sergeev V. (2008). Snova k voprosu o terminologii i okoloterminologicheskoy vozne vokrug logistiki [Back to the issue of terminology and near-terminological fuss around logistics.]. Resursyi. Informatsiya. Snabzhenie. Konkurentsiya, 2, 123-128. [in Russian]

Smyrchynskyi V. V. Smyrchynskyi A. V. (2000). Hlosarii lohistychnykh poniat i terminiv. Osnovy lohistychnoho menedzhmentu: navchalnyi posibnyk [Glossary of logistics concepts and terms. Fundamentals of logistics management: a textbook]. Ternopil: Ekonomichna dumka. [in Ukrainian]

Smoliar N.P. (2011). Pryntsypy klasyfikatsii diieslivnykh kompozytiv u suchasnii nimetskii movi [Principles of classification of composite verbs in modern German.]. Naukovi pratsi Kamianets-Podilskoho universytetu imeni Ivana Ohiienka. Filolohichni nauky, 26, 310-313. [in Ukrainian]

Statkevych A. H., Fenchuk O. O. (2010). Osoblyvosti navchannia anhliiskoi ta nimetskoi kompiuternoi terminolohii studentiv spetsialnosti "Informatyka» [Peculiarities of teaching English and German computer terminology to students majoring in "Computer Sciences".]. Visnyk Zhytomyrskoho derzhavnoho universytetu imeni Ivana Franka, 176-180. [in Ukrainian] Sterligov K. B. (2006). Terminologicheskaya baza znaniy i ponyatiynaya struktura terminologii logistiki $i$ ee definitsiy [Terminological knowledge base and conceptual structure of logistics terminology and its definitions]. Logistika segodnya, 2, 130-135. [in Ukrainian]

Sterligova A. N. (2004). Terminologicheskaya struktura logistiki [Terminological structure of logistics.]. Logistika i upravlenie tsepyami postavok, 4, 101-119. [in Ukrainian]

Elsen H. (2009). Komplexe Komposita und Verwandtes [Complex and related composites]. Germanistische Mitteilungen, 69, 57-71. [in German]

Erben J. (2006). Einführung in die deutsche Wortbildungslehre [Introduction to German word formation theory]. 5. Durchgearbeitete und ergänzte Auflage. Berlin: Erich Schmidt Verlag. [in German]

Lohde M. (2006). Wortbildung des modernen Deutschen [Word formation of modern German]. Tübingen: Narr. [in German]

Fleischer W., Barz I. (2012). Wortbildung der deutschen Gegenwartssprache [Word formation of the German contemporary language]. 4. völlig neubearbeitete Auflage. Berlin-Boston: De Gruyter (Studium). [in German]

Motsch W. (2004). Deutsche Wortbildung in Grundzügen [Basic word formation of German]. [2. Aufl.]. Schriften des Instituts für Deutsche Sprache. Bd. II. Berlin; New York. [in German] 